\title{
Обратите внимание!
}

\section{Статья отозвана (ретрагирована)}

\section{Статья}

Забузов О.Н., Желнов И.И. Доктринальная эволюция зарубежных взглядов на противодействие терроризму // Интернет-журнал «НАУКОВЕДЕНИЕ» 2014. № 6 http://naukovedenie.ru/PDF/86TVN614.pdf (доступ свободный). Загл. с экрана. Яз. рус., англ. DOI: 10.15862/86TVN614

отозвана (ретрагирована) редакцией журнала в соответствии с правилами отзыва (ретракции) Интернет-журнала «Науковедение»

http://naukovedenie.ru/retraction.php

В ходе дополнительной проверки выяснилось, что выводы, приведенные в статье, были ранее опубликованы в другом издании:

Забузов О.Н. Эволюция взглядов на противодействие терроризму в мире: критические выводы для России // Научные и образовательные проблемы гражданской защиты. 2013. №4. URL: http://cyberleninka.ru/article/n/evolyutsiya-vzglyadov-naprotivodeystvie-terrorizmu-v-mire-kriticheskie-vyvody-dlya-rossii

Редакция приносит извинения читателям за доставленные неудобства 
Интернет-журнал «Науковедение» ISSN 2223-5167 http://naukovedenie.ru/

Выпуск 6 (25) 2014 ноябрь - декабрь http://naukovedenie.ru/index.php?p=issue-6-14

URL статьи: http://naukovedenie.ru/PDF/86TVN614.pdf

DOI: 10.15862/86TVN614 (http://dx.doi.org/10.15862/86TVN614)

УДК 32.019 .5

\section{Забузог Нег Николаевич}

ФГБОУ ВПО «Московский государственный лингвистический университет»

Россия, Москва ${ }^{1}$

Доцент кафедры библиотечно-ик эnмационной деятельности Кандидат политических наук

E-Mail: zabuzov@mail.ru

Желнов Илья Игоревич

ФГБОУ ВПО «Московский государст е, чый лингвистический университет»

Россия, Москва

Заведуюши афедрой информационных технологий

Кандидат военных наук

E-Mail: jelnov-i@yandex.ru

\section{A \\ Доктринальная эвоџюция зарубежных взглядов \\ на протувидействие терроризму}

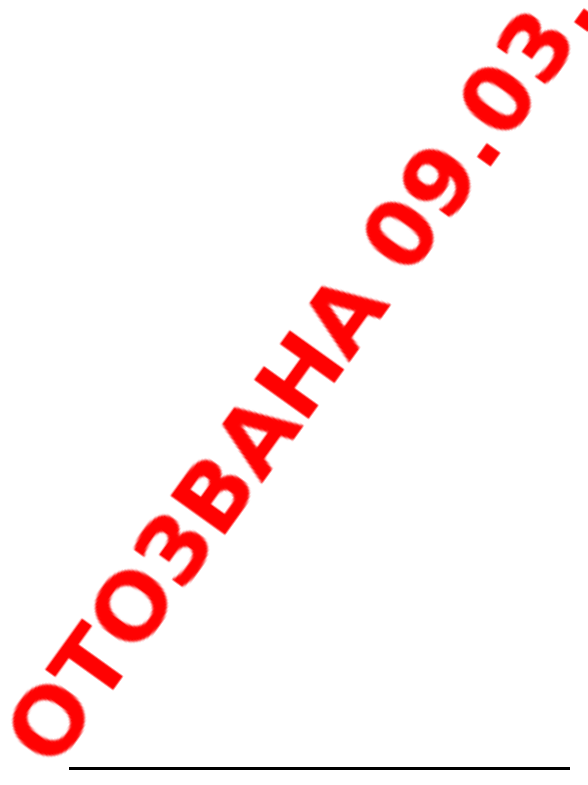

${ }^{1}$ 119034, Москва, ул. Остоженка 38 
Аннотация. В статье анализируются доктринальные взгляды ведущих государств мира в специфике противодействия терроризму. Отдельно исследованы подходы государств, которые в меньшей степени подверженных террористической угрозе: Финляндия и ФРГ. Заострено внимание на анализе нормативно-правовой базы и научных разработок в стра $а х$, которые в большей степени, подвержены террористической угрозе. К таким странам отн сены США и Великобритания. Отдельное место отведено анализу израильского опыта ( рьбе с терроризмом и прослежена динамика изменения израильских взглядов в протия олействии терроризму.

Проанализирована трансформация взглядов на борьбу с терроризмом ғадущих странах мира. Тенденции такой борьбы сводятся к уходу от исключительно силовою решения этой проблемы в сторону несилового, или названного нами, «социализированн с способа» борьбы. Одной из ключевых ролей в борьбе с терроризмом является противодей $\mathbf{1}$ ие распространению идеологии терроризма. Немаловажным фактором в такой борьбе является возможность выбить из-под ног террористов почву для насаждения идей терроризма.

Исследована тенденция вывода проблемы решения терго зма рядом государств из исключительно нормативно-правового поля, в несколько иноє. ұой агломерацией решения проблемы может выступать комплексность ее решения, - ен рассматривать проблему терроризма исключительно дискретной по отношению к об пу тву.

Ключевые слова: терроризм; террор; ти; трансформация; доктрина; «социализированный способ»; комплексность; идеоло ж; изменение; эволюция.

Ссылка для цитирования этой статьи:

Забузов О.Н., Желнов И.И. Доктринальная эволюция зарубежных взглядов на противодействие терроризму // Интернет-журнал «НАУКОВЕДЕНИЕ» 2014. № 6 http://naukovedenie.ru/PDF/86TVN614.pdf (доступ свободный). Загл. с экрана. Яз. рус., англ. DOI: 10.15862/86TVN614

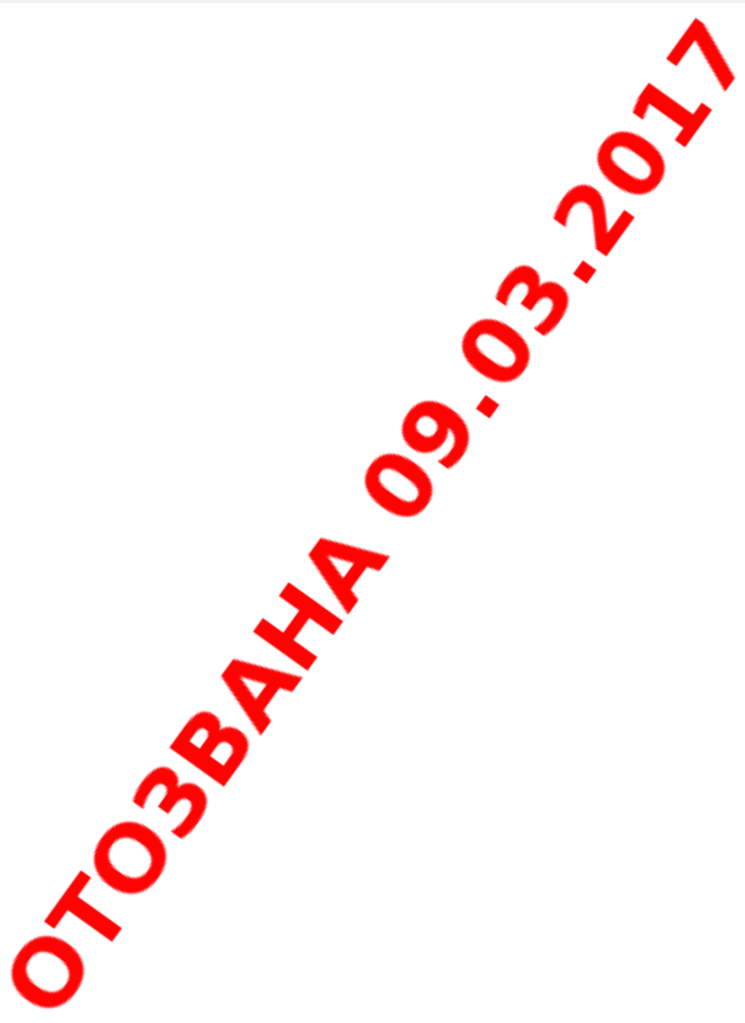


Как показывает повседневный опыт, вопросы антитеррористической политики (противодействия терроризму) не относятся к тем будничным политическим темам, которые обсуждаются широкой общественностью (как проблемы преступности, повышения цен или проблемы безработицы и др.). Тем не менее, интерес к этой политике, а Тасже заинтересованность в широкой информации по данным вопросам существует в обц стве. Стоит заметить, что такая заинтересованность начинает расти в геометрической прог ес сии, но не тогда, когда удалось предотвратить террористический акт, или обезвредит уередную террористическую группу, а в том случае, когда не удалось предотвратить террористический акт и количество людских жертв очень велико. Причем такого рода заинтебєс ванность со стороны отдельных граждан и общественности, заключается исключительно қ итике властей.

Авторы американского доклада «Глобальные тенденции 2025 года: иениившийся мир», выделяют несколько важных подразделов. Одним из таких подразделов я. тяется «Терроризм: хорошие и плохие прогнозы».

Терроризм не исчезнет к 2025 году, делают вывод оры доклада. Однако привлекательность его призывов может пойти на спад, если продол ится экономический рост, и безработица среди молодежи на Ближнем Востоке сократигс. Экономическая мотивация молодежи и развитие политического плюрализма, вероятно, от злекут определенные группы молодежи от вступления в ряды террористов. Но другие кө оые люди, одержимые иными устремлениями - желанием отомстить, стать «героями өметниками», - будут продолжать прибегать к насилию в претворении своих целей.

Некоторые правительства, возможно, отве « на растущий вызов терроризма и внутренние угрозы путем расширения масштабов Ре твий сил безопасности, развития средств наблюдения, более активным использованием спецнгза. Контртеррористические миссии будут более интенсивными в городских операциях в связи с ростом урбанизации.

Другие правительства, декларируя необходимость обеспечения безопасности, станут больше контролировать потоки внешнх беженцев и иммигрантов, будут выстраивать баррикады и стены вокруг своих территорий, чтобы затруднить туда доступ. Коммуникации через КПП могут стать преобладающимь зо многих обществах, когда элиты будут стремиться обезопасить себя от внутренних терр ро стических угроз ${ }^{2}$.

Проанализируем, какие походы сложились в зарубежных странах в области противодействия терроризму?

Преподаватель полицє яс ого колледжа из Финляндии, С. Хэтонн, отмечает, что борьба с терроризмом в Финляндш ғацелена на определение максимально ранней стадии опасности, угрожающей Финляндии е предотвращение. Для достижения указанной цели руководство Финляндии использует өлдющие методы.

1. Анализ и мғморинг и международного терроризма, а так же явлений, связанных с ним.

2. Вскры у событий, связанных с террористической деятельностью, контроль над их развитием и ситием преступности, связанной с терроризмом, всесторонняя оценка угрозы их возникне ения на территории страны.

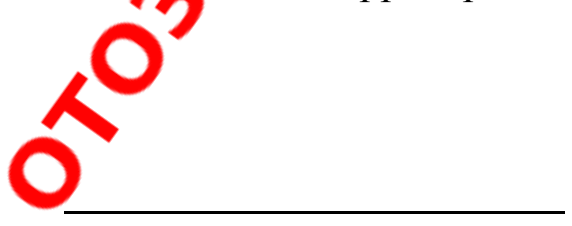

\footnotetext{
${ }^{2}$ Growing Potential for Conflict / Global Trends 2025: A Transformed World // http://www.dni.gov/files/documents/Newsroom/Reports\%20and\%20Pubs/2025_Global_Trends_Final_Report.pdf.
} 
3. Определение лиц и организаций располагающихся на территории Финляндии, представляющих потенциальную угрозу ${ }^{3}$.

Становится понятно, что в Финляндии борьба с терроризмом сведена исключите но к деятельности специалистов по противодействию терроризма. В тоже время мы не наблюдаем привлечение в противодействие терроризму иных субъектов такой деятельности, моме как государственных структур и органов.

Очевидно, что Финляндия в социальном плане достаточно благополучная сқрана, и мы не можем припомнить каких-либо террористических проявлений на ее территоßил. Этот тезис касается в первую очередь отсутствия основ развитию благоприятной г эч ы терроризма внутри самой страны. Можем заключить, что оснований для развития «эксцентричного недовольства» перерождающегося в терроризм в Финляндии нет. Однако, с стоит списывать со счетов возможность проявления террористической угрозы извне. I Р главной движущей идеологемой террористов будет лозунг такого содержания: «Дажов такой благополучной стране вы не чувствуете себя защищенными от террористическойоднности». В связи с этим главное в противодействии терроризму в Финляндии является нед яущение, назовем это так, на свою территорию любого террористического элемента. Буд то, отдельный террорист, группа, ячейка, или целая организация. Стоит заметить, что Уэтонн, видит главную угрозу стране исходящую от исламского радикализма и терроризм

Генеральная цель политики немецкого государсть аключается в том, чтобы сократить, насколько возможно, угрозу безопасности Германи мировому сообществу со стороны глобализирующегося терроризма, а также немецким љәжданам и их интересам. Уменьшению опасности, отмечает автор, служит, в первую оче еш, превентивная борьба с причинами и идеологической базой терроризма. Террористические структуры должны действенно уничтожаться через оказание давления на ход розыска и расследований, а также решительного образа действий против террористических систем, а террористические и поддерживающие их государственные и негосударственные акторы и симпатизирующие им лица - подвергаться устрашению.

Становится понятно, что руково ство Германии в своей политике выделяет метод устрашения, что своего рода можно ( $а$ рактеризовать как террор со стороны государства.

Снижение уязвимости Гермаиии в целом, защита населения и немецких интересов служат к тому же эффектиғле технические, персональные и организационные меры безопасности. Как считает ағ 2 , причина и симптомы терроризма - комплексные, ввиду этого для предотвращения и преодоления международного терроризма руководство Германии использует многосторон Ф, общеполитический и превентивный подходы. Обязательной предпосылкой для усп ш ого преодоления международного терроризма, с немецкой точки зрения, является строгое соблюдение действующего международного права, положений и прав человека. Германия настойчиво выступает за главенствующую роль Организации Объединенных Надй в противодействию международному терроризму. Отмеченные положения при этой борьбе международную легитимность, общемировую правовую и политическуюло товерность, а также возможность выбора средств для ее осуществления. Это является важь населением, ировой общественностью и умеренных мусульманских государств, организаций и группц о ок в споре по вопросу о международном терроризме.

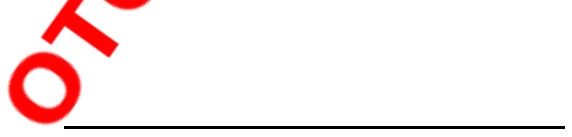

\footnotetext{
${ }^{3}$ Хэтонн С. Противодействие терроризму в Финляндии // Вестник Санкт-Петербургского университета МВД России. 2010. № 2. С. 44-45.
} 
В связи с этим, по мнению немецкого политического руководства, предотвращение и преодоление терроризма понимается как комплексная, общеполитическая задача. С помощью ее решения Федеральное правительство хочет справиться с интегративными и многоуровневыми причинами и формами проявления международного терроризма. Автон $\mathrm{X}$. Бюль, в заключение отмечает, что проведение изолированных мер не рассматриваету как сулящее успех ${ }^{4}$.

Можем отметить, что доктринальные положения, отмеченные автором ста ви, носят конструктивный аспект. Согласимся и с тем, что проблему борьбы с терр мизмом стоит рассматривать как комплексную проблему. И, руководство Германии, по край ййере, в своих намерениях рассматривает проблему противодействия терроризму как интегративную политическую проблему, с соответствующим комплексным подходом к е ю шению. Не можем не назвать положительным фактом и то, что руководство ФРГ не рассма р вает сугубо силовые меры как наиболее успешные в сфере борьбы с терроризмом.

Дж. Стивенсон, автор статьи о роли вооруженных сил Велико итании в борьбе против терроризма, отмечает, что в Великобритании, в отличие США, нет жесткого законодательного запрета на использование вооруженных сил ннури страны. Автор заостряет свое внимание на определении места и роли ВС Великобри энии в борьбе с терроризмом, а также исследует значение гражданских властей в этой деят у мости.

По запросу (как правило) соответствующего ц палиции - через министерство внутренних дел и с формального согласия министерст обороны - британские военные могут оказывать специальную военную помощь гражда қум властям. Это так называемый «Внутренний антитеррор».

В тоже время, практика показала, что британская армия оказалась не готова к радикально новым требованиям, которые могут быть предъявлены к военным в связи с появлением новой, апокалиптической формы терроризма, так отличающейся от относительно умеренного использования политического насилия Ирландской Республиканской Армией.

Руководящая роль в борьбе пр тив терроризма на британской земле принадлежит министерству внутренних дел, а а ии всегда отвечала за физическую оборону, в смысле охраны воздушного пространства утерриториальных вод. В общем, мы не нашли достаточного количества доказательств того, что м нистерство обороны восприняло серьезно необходимость переосмыслить состояние вфоженных сил, чтобы они были в состоянии оказать необходимую поддержку гра жанским властям по обеспечению внутренней безопасности в случае крупномасштабного террористического акта в Великобритании ${ }^{5}$, заключает автор статьи.

Израильские автю А. Кашнер и А. Ядлин рассматривают борьбу с терроризмом на фоне так называемой токтрины справедливой войны». Заметим, так же что Израиль находится в перманентном со тс ниии войны с терроризмом. Не маловажным является и тот факт, что в Армии обороны К ааиля служат все граждане призывного возраста в течение трех лет.

Докумечт, который представляют авторы, был разработан в возглавляемой ими группой в Колледже ииональной обороны (IDF) Армии обороны Израиля. Авторы считают, что

${ }^{4}$ Büh H. T. Die Verhütung und Bekämpfung des internationalen Terrorismus. Beitrag der Bundeswehr zum ressortübergreifew n Ansatz / Europäsce Sicherheit, № 1. 2006. S. 69-73.

${ }^{5}$ Stevenson Jonathan. The Role of the Armed Forces of the United Kingdom in Securing the State against Terrorism // Armies in Homeland Security: American and European Perspectives / Edited by John L. Clarke Washington, D.C.: National Defense University Press, 2006. S. 21-36. 
предложенные принципы, изложенные в нем, практически применимы в любых схожих обстоятельствах.

Структура доктрины представлена тремя частями, включающие в себя несю тько подразделов каждая.

Так, часть I. «Принципы борьбы с террором: уровень государства» включает Љео̆я два принципа.

1. Принцип самообороны.

2. Принцип миссии.

Первые два принципа предлагается применять на уровне государства, когда оно сталкивается с террористической угрозой. Они являются общими отпр Њыми точками для обсуждения моральных и этических аспектов борьбы демократическс го государства против терроризма.

Часть II. Принципы борьбы с террором. Превентивные вя ннғте действия, состоит из шести принципов.

1. Принцип военной необходимости.

2. Принцип разграничения.

3. Принцип военной соразмерности.

4. Принцип низкой вероятности.

5. Принцип времени.

6. Принцип профессионального понимания.

Борьба государства против терроризма ведется на двух разных, хотя и взаимосвязанных полях боя. Так как террористические акты осуществляются с целью убийства или иного поражения людей, являющихся частью оғрделенного населения, для того чтобы посеять страх среди этого населения. Первое направл чие борьбы - борьба по защите населения от убийств и ранений, так как каждый раз, когда оди гибнут от рук террористов, сохраняется и угроза дальнейшей гибели, и поэтому искетенить страх среди населения становится невозможным. И поэтому вторая арена борьбы - это з щита населения от страха.

Часть III. Принципы бо часть состоит из трех основн

1. Принцип постояного предупреждения.

2. Принцип комп 현ии.

3. Принцип огюативного сдерживания.

Государстве дая деятельность по борьбе за общественное сознание должна вестись по разным направленм. Первое направление - это внутреннее информационное пространство. Цель - сделать чк, чтобы население не только не поддавалось страху, но и поддерживало антитеррориє лескую деятельность армии и других силовых структур государства. Второе направление - это международное информационное пространство. Цель - убедить обществ Нн сть разных стран в том, что борьба с терроризмом ведется эффективно и с соблю ением моральных норм. Третье направление - это общественное мнение населения райов базирования террористов. При этом первая цель заключаются в том, чтобы убедить насе. -ие, что терроризм не приведет ни к каким политическим или идеологическим достижениям. Вторая цель - дать понять жителям, что антитеррористическая война - это война против террористической деятельности, которая планируется и ведется террористами, как 
отдельными лицами, так и организациями. Антитеррористическая война не ведется против всего окружающего населения, даже если оно и симпатизирует террористам 6 .

То есть, на наш взгляд, структура документа, да и сами принципы, отраженные доктрине достаточно условно возможно представить в виде пирамиды, где в ее вершиюлежит идеология государственного противодействию терроризму, которая опирается наскловое решение проблемы терроризма и информационно-психологическое. Последнее стам своей целью активное влияние на общественное мнение, как жителей страны, всего мирового сообщества, так и на ту часть населения, которая открыто/закрыто симпатизируд-террористам. Стоит заметить, что в этом ряду стоит выделить еще и идеологический акти геррористов, на который так же должно вестись информационно-психологическое воздейстьие. Естественно, способы, средства и методы такого рода воздействия должны быть уника в ьими и отличными от тех, которые используются при воздействии на групповое мнение.

«Стратегия борьбы с терроризмом» в США призвана обеспешшсь две ключевые задачи: защитить Соединенные штаты, их граждан, их друзей и союзнов по всему миру от террористических атак и, одновременно, создать максимаю неблагоприятную для функционирования терроризма международную среду. қлю выполнения этих задач администрация США представила так называемую стратегию «щетырех D».

1. Defend - защитить.

2. Defeat - уничтожить.

3. Deny - отказать.

4. Diminish - уменьшить.

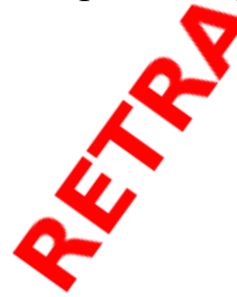

Естественно главным направлением антитеррористической стратегии является защита жителей и интересов США как на американской территории, так и за рубежом, путем укрепления обороноспособности страны, а также распознавание и нейтрализация террористической угрозы на максимальн аранней стадии ${ }^{7}$.

Можем заключить, что в этой өриканской Стратегии руководством США ставится решение задач по предупреждению т роризма в обособленном виде. То есть без рассмотрения основ зарождения и развития тя роризма как внутри США, так и мире. Не ставится руководством США, и создание превентивных мер противодействию терроризму, т.е. рассмотрение такого явления kang герроризм в Стратегии не подразумевает решение проблем террористической угрозы и хо ия из этнических, культурных, социально-экономических и иных истоков зарождения такөго явления.

В противодейс современному международному терроризму, отмечают американские эксперты, нужно основательно менять подходы. Одних силовых методов, карательной полит у уже недостаточно. На смену уничтоженным бандформированиям и отдельным боевйм приходят другие «люди действия». В итоге нетронутыми остаются так называемье «оди мысли» - носители экстремистских идей, или, если высказаться глобальнее, генраторы идеологии. Необходима значительная првентивная работа по созданию так фоциально-экономической и толерантной среды в обществе, которая отторгала бы террори공. Необходим конструктивный и открытый диалог политиков, правозащитников,

${ }^{6}$ Asa nusher, Amos Yadlin. Military Ethics of Fighting Terror: An Israeli Perspective // Journal of Military Ethics, 2005. Vol. 4. No. 1, P. 3-32.

${ }^{7}$ Стратегия борьбы с терроризмом Соединенных Штатов Америки //

http://studies.agentura.ru/tr/reform/uscounterterrorsystem/ (дата обращения: 11.09.2014 г.). 
представителей неправительственных организаций, где обсуждались бы все проблемы и противоречия, тормозящие борьбу с терроризмом ${ }^{8}$.

Нет оснований не согласиться с американскими экспертами в вогрсах противодействию террористам. Учитывая, что современные террористичеgие и экстремистские организации приобретают все более сетевой, децентрализированнь ук.вень своей деятельности, где ключевой основой является не система управления и взаимодйствия, а во многом разобщенные группы, но объединенные одной идеологией.

На схожих позициях стоит исследователь Московского бюро по прй человека С. Беликов. Исследуя структуру боевых террористических организаций, авт $\mathfrak{D}$ тмечает, что в настоящее время деятельность боевых террористических организаций өрганизуется на принципах «сетевого» сопротивления или сопротивления без лидера - м время разрабатываемой и апробированной в ряде зарубежных стран, в о и числе некоторыми ультраправыми объединениями («Комбат-18» в Англии, «Порядок» США). При реализации этой системы каждая относительно небольшая группа ультрапра х радикалов действует полностью автономно, никому не подчиняется и в своей деяльности ориентируется на совокупность общих и распространенных расистских и напиякких идей и принципов. В некоторых случаях методика имеет несколько иной характер. Чааример, «Фракция коричневая армия» в ФРГ строила свою деятельность на основе сам слтельных действия отдельных ячеек, не связанных друг с другом, но управляемых из ед 4 о центра 9 .

Как отмечает Джон П. Терри, так же анализиру деятельность США: «Традиционные средства разрешения конфликтов, основанные на пра у традиционной практике, не работают, потому что терроризм по определению скрытен в с 9 действиях, не имеет формальных связей с государством-спонсором и проводится в жизнь с высокой степенью жестокости. Дипломатия и стремление к примирению могут быть бесполезны, когда имеешь дело с государством, которое отрицает свои действия и всячески стремится избежать нормального, законного взаимодействия между странами.

Однако следует отметить, что и непинудительные меры борьбы с терроризмом также важны. Эксперт по борьбе с терроризмом доктор Уильям Фаррелл отмечает: «Индивидуальная или коллективная дипломатия, кот ра могла бы повлиять на действия террористической группы или государства-спонсора, Д) жна рассматриваться и применяться в первую очередь». Как вариант, до применения военной силы необходимо еще рассмотреть политические и экономические санкции» ${ }^{10}$.

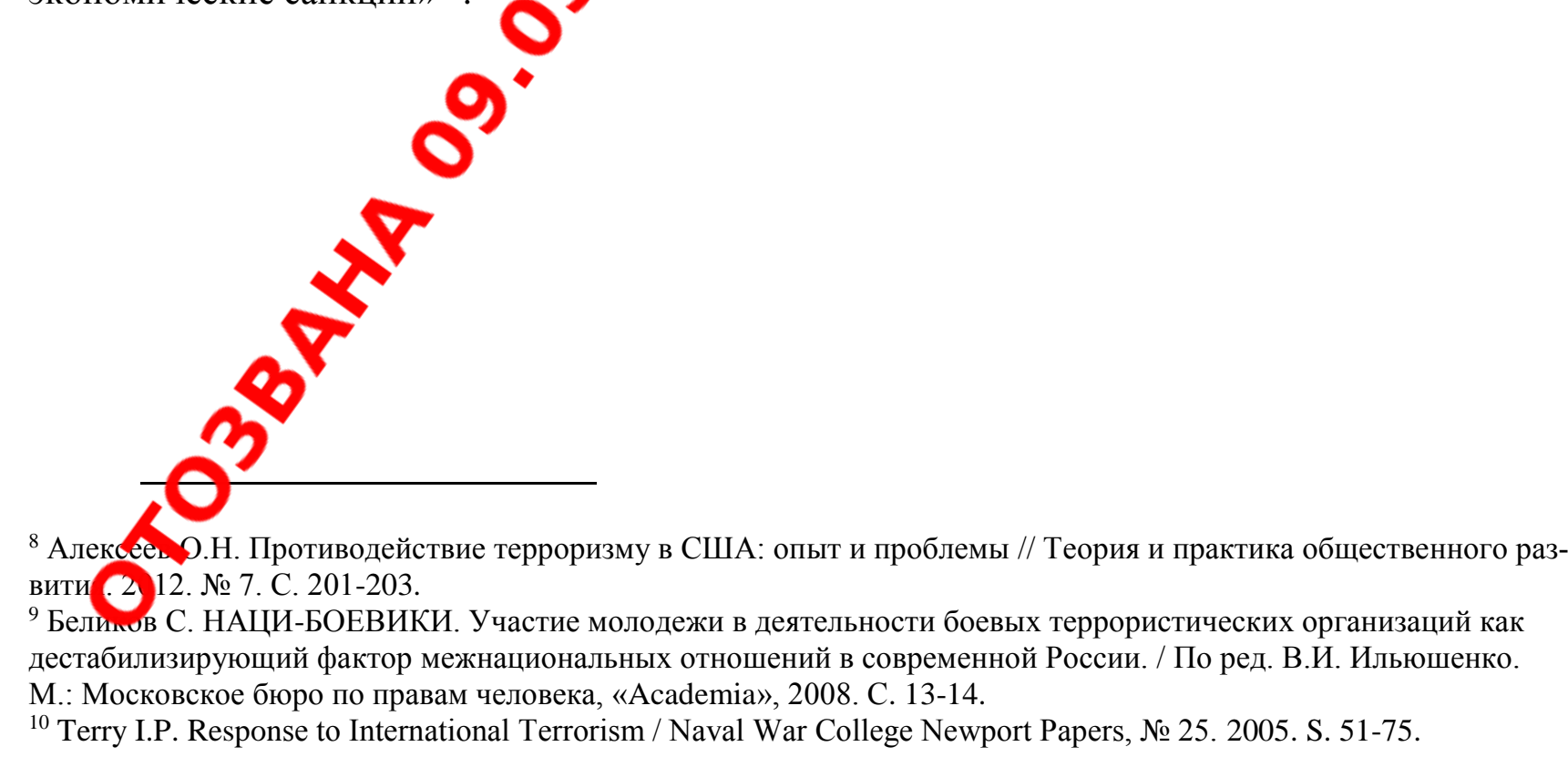


Подведя итог анализу борьбы с терроризмом в зарубежных странах, можем заключить, что особенности противодействия в этих странах определяются тем террористическим фоном, который сложился вокруг и внутри этих стран.

Отметим так же, что современный этап борьбы с терроризмом сводится нек явно силовому способу противодействию терроризма. В политике большинства государстрасе. отчетливо прослеживается уход от исключительной борьбы с терроризмом силовымм тодами в сторону несилового, или иными словами сказать «социализированного способа) борьбы с этим явлением. Главенствующим сегодня становится противодействие идеоло иерроризма и ликвидации благоприятной почвы для развития терроризма. Причем, ряд го эларств выводит проблему противодействия терроризму исключительно из законодательного, детерминированного поля борьбы с терроризмом, в принципиально политическое решение проблемы.
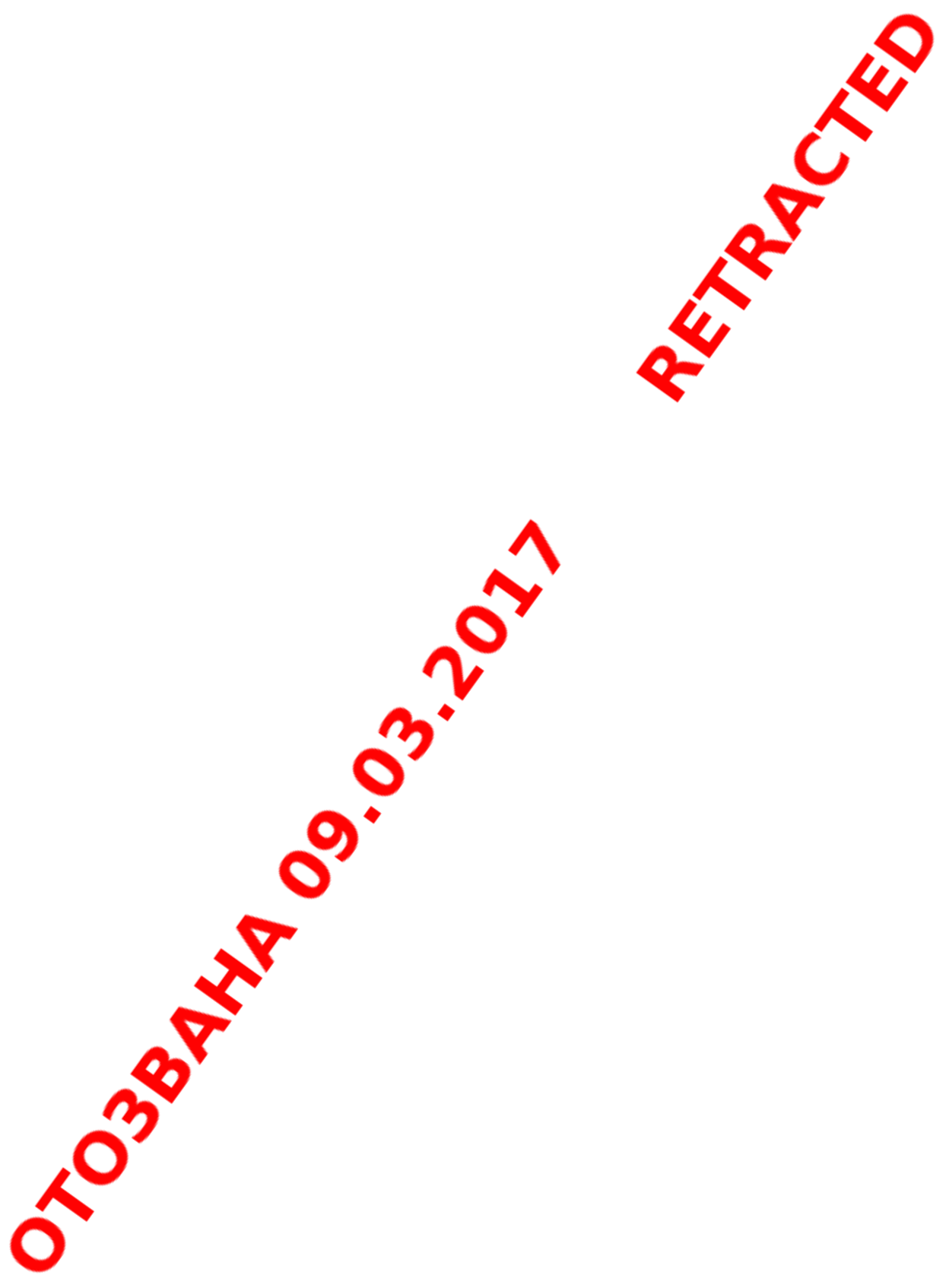


\section{ЛИТЕРАТУРА}

1. Алексеев О.Н. Противодействие терроризму в США: опыт и проблемы // Теория и практика общественного развития. 2012. № 7. С. 201-203.

2. Беликов С. НАЦИ-БОЕВИКИ. Участие молодежи в деятельности о евых террористических организаций как дестабилизирующий фактор межнациональных отношений в современной России. / По ред. В.И. П.уюшенко. М.: Московское бюро по правам человека, «Academia», 2008. С. 13-14

3. Волков Е.И., Баженов Р.И. Разработка программной с тей «Сканер социальных связей» // Современные научные исследования и инғовации. 2014. № 5 [Электронный ресурc]. URL: http://web.snauka.ru/issues \&, 14/05/34321 (дата обращения: 05.08.2014).

4. Забузов О.Н. Эволюция взглядов на противодейстме терроризму в мире: критические выводы для России // Научные и ор зовательные проблемы гражданской защиты. 2013. № 4 (19). С. 88-96.

5. Стратегия борьбы с терроризмом Соеди енных Штатов Америки // http://studies.agentura.ru/tr/reform/uscounterterrors yorem/ (дата обращения: 11.09.2014 г.).

6. Хэтонн C. Противодействие террориз у Финляндии // Вестник СанктПетербургского университета МВД Росљии.2010. № 2. С. 44-45.

7. Шолохов М.Я., Желнов И.И., Яроцкая Л.В. Психодиагностика в профориентационной работе с подросками и старшеклассниками // Мир науки. 2014. № 1. [Электронный pecypc]. URL: http://elibrary.ru/download/73964822.pdf (дата обращения: 05.10.2014).

8. Bühl H.J. Die Verhütung und Rekämpfung des internationalen Terrorismus. Beitrag der Bundeswehr zum ressortüber-g eifenden Ansatz / Europäsce Sicherheit, № 1. 2006. S. 69-73.

9. Growing Potential for Q nflict / Global Trends 2025: A Transformed World // http://www.dni.gov/fifes/acuments/Newsroom/Reports\%20and\%20Pubs/2025_Glob al_Trends_Final_Ropor.pdf (дата обращения: 11.10.2014).

10. Kasher A., Yadli A Military Ethics of Fighting Terror: An Israeli Perspective // Journal of Military Ethics 2005. Vol. 4. No. 1, P. 3-32.

11. Stevenson The Role of the Armed Forces of the United Kingdom in Securing the State agains Terrorism // Armies in Homeland Security: American and European Perspec os / Edited by John L. Clarke Washington, D.C.: National Defense University Press, 0. 6. P. 21-36.

12. TE I.P. Response to International Terrorism // Naval War College Newport Papers. ㄱำ. № 25. P. 51-75. 
Ilia Zhelnov

Moscow State Linguistic University

Russia, Moscow

E-Mail: zabuzov@mal.ru

Ole? abuzov

Moscow State Linguistic Wniversity

Bussia, Moscow

E-Mail: jelnoy-i@yandex.ru

\title{
Doctrinal evolution of the foreign $y$ ews on the counter-terrorism
}

\begin{abstract}
The article analyzes the doctrinal views of the vord leading states in the matter of counter-terrorism. The approaches of the states, which are less $\gg$ posed to a terrorist threat, such as Finland and Federal Republic of Germany, have been conside e ceparately. The attention was focused on the analysis of the regulatory and legal framework and ienific researches in states with a higher degree of a terrorist threat. These states include the USA ad Great Britain. Special emphasis has been placed on the analysis of Israeli counter-terrorism exprivace as also the dynamic pattern of Israeli views on counter-terrorism has been traced.
\end{abstract}

In this article has been analyzed the transformation of views on the fight against terrorism in the world leading states. The trend of this fight reduces to the moving away from only the force solution of this problem and shifting to more soft methods or as we have named it «socialized method». One of the key points in the fight against terrorisn 1 interdiction of terrorism ideology spread. An important factor in this fight is an opportunity to cu he ground from under feet of a terrorist so that he can no longer plant terrorism ideas.

In this article has been analyzec the trend of moving the problem of fighting against terrorism by a series of states from only regulatory and legal framework to a different framework. An agglomeration of this problem 's solation can involve its`complexity, i.e. the problem of terrorism should not be considered entire separate from the society.

Key words: terror $S$ terror, networks, transformation, doctrine, «socialized method», complexity, ideology, cha ng s, evolution.

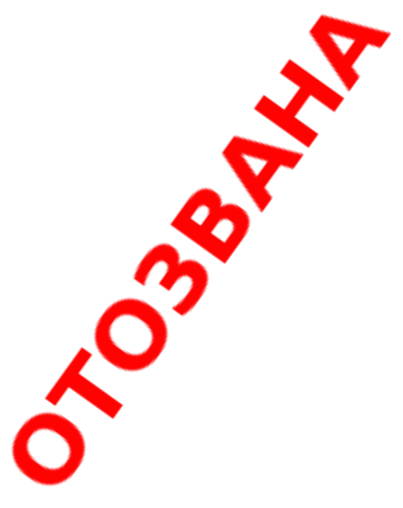




\section{REFERENCES}

1. Alekseev O.N. Protivodeystvie terrorizmu v SShA: opyt i problemy // Teoriya i praktika obshchestvennogo razvitiya. 2012. № 7. S. 201-203.

2. Belikov S. NATsI-BOEVIKI. Uchastie molodezhi $\mathrm{v}$ deyatel'nosti be vykh terroristicheskikh organizatsiy kak destabiliziruyushchiy faktor mezhnat io al'nykh otnosheniy v sovremennoy Rossii. / Po red. V.I. Il'yushenko. M.: Mosk60 soe byuro po pravam cheloveka, «Academia», 2008. S. 13-14.

3. Volkov E.I., Bazhenov R.I. Razrabotka programmnoy sistemy «S nan sotsial'nykh svyazey»// Sovremennye nauchnye issledovaniya i innovatsii. 2014. 5 [Elektronnyy resurs]. URL: http://web.snauka.ru/issues/2014/05/34321 obrashcheniya: 05.08.2014).

4. Zabuzov O.N. Evolyutsiya vzglyadov na protivodeyotyie terrorizmu $\mathrm{v}$ mire: kriticheskie vyvody dlya Rossii // Nauchnye i obrazovatel. problemy grazhdanskoy zashchity. 2013. № 4 (19). S. 88-96.

5. Strategiya bor'by $\mathrm{s}$ terrorizmom Soedin nnykh Shtatov Ameriki // http://studies.agentura.ru/tr/reform/uscounterterrors yorem/ (data obrashcheniya: 11.09.2014 g.).

6. Khetonn S. Protivodeystvie terrorizmu v Fi 1ly andii // Vestnik Sankt-Peterburgskogo universiteta MVD Rossii. 2010. № 2. S.

7. Sholokhov M.Ya., Zhelnov I.I., Yarotskaya L.V. Psikhodiagnostika v proforientatsionnoy rabote s podrostkamı starsheklassnikami // Mir nauki. 2014. № 1. [Elektronnyy resurs]. URL: http://elibrary.ru/download/73964822.pdf (data obrashcheniya: 05.10.2014).

8. Bühl H.J. Die Verhütung und Rekämpfung des internationalen Terrorismus. Beitrag der Bundeswehr zum ressortüber-g eifenden Ansatz / Europäsce Sicherheit, № 1. 2006. S. 69-73.

9. Growing Potential for Q nflict / Global Trends 2025: A Transformed World // http://www.dni.gov/fifes/acuments/Newsroom/Reports\%20and\%20Pubs/2025_Glob al_Trends_Final_Roport.pdf (data obrashcheniya: 11.10.2014).

10. Kasher A., Yad in A. Military Ethics of Fighting Terror: An Israeli Perspective // Journal of Military Ethics, 2005. Vol. 4. No. 1, R. 3-32.

11. Stevenson The Role of the Armed Forces of the United Kingdom in Securing the State agains Terrorism // Armies in Homeland Security: American and European Perspec os / Edited by John L. Clarke Washington, D.C.: National Defense University Press, No6. R. 21-36.

12. Te I.P. Response to International Terrorism // Naval War College Newport Papers.

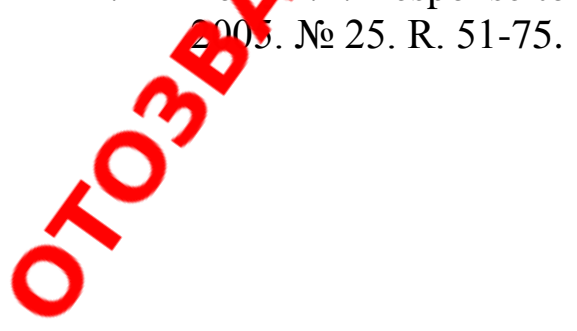

